function of the carotid body. Advances in Biochemical Psychopharmacology, Edited by Costa, E. and Gessa, G.L., Vol. 16, p. 265-274, Raven Press, New York (1977)

7) Zapata, P.: Modulatory role of dopamine on arterial chemoreceptors. Advances in Biochemical Psychopharmacology, Edited by Costa, E. AND Gessa, G.L., Vol. 16, p. 291298, Raven Press, New York (1977)

8) HeSs, A. AND ZAPATA, P.: Innervation of the cat carotid body-normal and experimental studies. Fedn. Proc. 31, 1365-1382 (1972)

9) Jacobs, L. ANd Comroe, J.H. JR.: Stimulation of the carotid chemoreceptors of the dog by dopamine. Proc. natn. Acad. Sci. 59, 1187-1193 (1968)

10) Black, A.M.S., Comroe, J.H. JR. AND JACOBS, L.: Species difference in carotid body response of cat and dog to dopamine and serotonin. Am. J. Physiol. 223, 1097-1102 (1971)

11) Zapata, P.: Effects of dopamine on carotid chemo- and baroreceptor in vitro. J. Physiol. 244, 235-251 (1975)

12) Libet, B. And Tosaka, T.: Dopamine as a synaptic transmitter and modulator in sympathetic ganglia-a different mode of synaptic action. Proc. natn. Acad. Sci. U.S.A. 67, 667-673 (1970)

13) Welsh, M.J., Heistad, D.D. and Abboud, F.M.: Depression of ventilation by dopamine in man. Evidence for an effect of the chemoreceptor reflex. J. clin. Invest. 61, 708-713 (1978)

14) Huckauf, H., Ramdohr, B. ANd SChröder, R.: Dopamine induced hypoxemia in patients with left heart failure. Int. J. clin. Pharmacol. 14, 217-224 (1976)

\title{
CORRELATION BETWEEN VASODILATOR POTENCIES OF $\beta$-ADRENOCEPTOR BLOCKING DRUGS AND THEIR CHEMICAL STRUCTURES
}

\author{
Norio HIMORI \\ Department of Pharmacology, Tohoku University School of Medicine, Sendai 980, Japan
}

Accepted October 29, 1979

Nakano and Kusakari (1) and Shanks (2) reported that an i.a. injection of propranolol produced relatively short-lived vasodilation and Shanks suggested that the local anesthetic action of propranolol was probably involved in the vasodilation. Recently, our group found that alprenolol directly dilates several vascular beds in anesthetized dogs and we suggested that the hypotensive effect of i.v. alprenolol would be largely due to a direct vasodilator action (3). The present study was designed to determine possible relationships between chemical structures and vasodilator potencies of $\beta$-adrenoceptor blocking drugs.

Experiments were carried out on 28 mongrel dogs of either sex, weighing between 9.5$17 \mathrm{~kg}$ and anesthetized with sodium pentobarbital $(30 \mathrm{mg} / \mathrm{kg}$ i.v.). The femoral arterial bed was perfused through the cannulated femoral artery with blood from the carotid artery, using a cam pump (Tokyo Rikakikai Co., Model 16). Perfusion pressure was kept constant at approx. $120 \mathrm{~mm} \mathrm{Hg}$ by shunting a fraction of blood through a Starling pneumatic resistance to the external jugular vein (3). Sodium heparin was given at a dose of 500 units/ $\mathrm{kg}$ i.v. Blood flow through the femoral artery was measured with an electromagnetic 
flowmeter (Nihon Kohden, MF-46-3). Twenty-one $\beta$-adrenoceptor blocking drugs listed in Tables 1 and 2 were used. Unless otherwise stated, the $\beta$-adrenoceptor blocking drugs used in this study were racemic mixtures. Drug solutions in a volume of $100 \mu 1$ or less (in $5 \mathrm{sec}$ ) were injected using microsyringes, into the rubber tubing just proximal to a cannula placed in the femoral artery.

The basal blood flow through the femoral vascular bed at a constant perfusion pressure

TABLE 1. Relative vasodilator potencies of $\beta$-adrenoceptor blocking drugs on a weight basis as determined in the femoral arterial bed

\begin{tabular}{lc}
\hline \multicolumn{1}{c}{ Drugs } & Relative Potencies*1 \\
\hline Bunitrolol & $11.0 \pm 2.40$ \\
Alprenolol & $8.5 \pm 1.91$ \\
d-Alprenolol & $8.0 \pm 2.10$ \\
Oxprenolol & $7.2 \pm 1.71$ \\
Bupranolol & $6.1 \pm 1.40$ \\
Bunolol & $2.8 \pm 0.41$ \\
Ko 592 & $2.1 \pm 0.44$ \\
Propranolol & 1.0 \\
d-Propranolol & $1.0 \pm 0.20$ \\
Pindolol & $0.9 \pm 0.18$ \\
Carteolol & $0.4 \pm 0.08$ \\
Timolol ${ }^{* 2}$ & $<0.3$ \\
Sotalol & $<0.2$ \\
Atenolol & $<0.2$ \\
Nadolol & $<0.1$ \\
Practolol & $<0.03$ \\
\hline
\end{tabular}

${ }^{* 1}$ Arbitrary unit: Propranolol $=1.0 .^{* 2}$ Levo type

TABLE 2. Relative vasodilator potencies of mono-substituted methyl or chloro analogues of isopropylaminophenoxypropanol

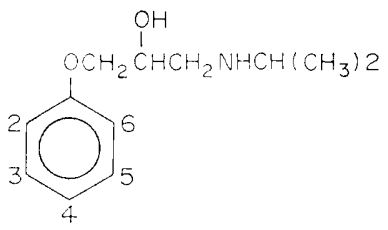

\begin{tabular}{ccc}
\hline Position & Methyl & Chloro \\
\hline 2 & $11.5 \pm 1.2$ & $9.2 \pm 0.6$ \\
3 & $2.1 \pm 0.3$ & $1.7 \pm 0.2$ \\
4 & $($ Ko 592$)$ & 1 \\
\hline
\end{tabular}

The potency of 4-substituted methyl or chloro analogues was arbitrarily assigned 1. 3-Chloro analogue was $2.4 \pm 0.2$ times more potent than propranolol. 
of approx. $120 \mathrm{~mm} \mathrm{Hg}$ was $42 \pm 3.7(\mathrm{n}=28) \mathrm{ml} / \mathrm{min}$. Single i.a. administrations of all the $21 \beta$-adrenoceptor blocking drugs produced an increase in blood flow. Increases in blood flow produced by these drugs, except for timolol, sotalol, atenolol, nadolol and practolol were dose-dependent. In the case of propranolol, the threshold dose was approx. $0.03 \mathrm{mg}$, and at 0.1 and $0.3 \mathrm{mg}$ the mean increase in blood flow amounted to $10 \pm 2.3$ and $18 \pm 4.5$ $(\mathrm{n}=6) \mathrm{ml} / \mathrm{min}$, respectively (approx. 20 and $40 \%$ of the basal blood flow). Dose-response curves for these $\beta$-adrenoceptor blocking drugs were constructed from data obtained from 3-6 experiments for each drug and their relative potencies were determined from their doseresponse curves on the basis of doses causing an increase in blood flow by $10-15 \mathrm{ml} / \mathrm{min}$. The values are tabulated in Table 1. Relative vasodilator potencies of ortho-, meta- or para-substituted methyl and chloro analogues of isopropylaminophenoxypropanol are also presented in Table 2. In both methyl and chloro analogues, the ortho-position gave the highest potency and para-position the lowest.

The present results clearly indicate that $\beta$-adrenoceptor blocking drugs having a substituted ortho-position, e.g. bunitrolol (cyano), alprenolol (allyl), oxprenolol (allyloxy), and bupranolol (methyl) generally have a potent vasodilator action (Table 1). As seen in Table 1, the vasodilator potency of $d$-alprenolol or $d$-propranolol was not significantly different from that of the respective racemic mixture. Furthermore, pindolol (4) and carteolol (5) or timolol (6) which have a potent $\beta$-adrenoceptor blocking action increased blood flow only slightly. Thus, it is obvious that the vasodilator action of these $\beta$-adrenoceptor blocking drugs is not due to their blocking action on pre- and post-synaptic $\beta$ adrenoceptors. It is also unlikely that the vasodilation is concerned with their local anesthetic actions, because their relative potencies for the local anesthetic action differed markedly from those for the vasodilator action, as reported previously (3). As regards the mechanism underlying this distinct vasodilator action of $\beta$-adrenoceptor blocking drugs, we have already proposed that $\beta$-adrenoceptor blocking drugs probably inhibit calcium transport $(3,7)$. The inhibition of calcium transport by pronethalol and propranolol in cardiac muscle has already been suggested by Fleckenstein et al. (8). Among mono-substituted analogues of isopropylaminophenoxypropanol, ortho-substituted analogues were the most potent in producing vasodilation (Table 2). The ortho-substituted analogues have been reported to be the most potent $\beta$-adrenoceptor blockers $(9,10,11)$. Whether or not these structural requirements are essential for both $\beta$-adrenoceptor blocking activity and vasodilating activity remains the subject of ongoing studies.

Acknowledgement: I thank Prof. N. Taira for pertinent suggestions regarding experiments and preparation of the manuscript.

\section{REFERENCES}

1) Nakano, J. and Kusakari, T.: Effect of propranolol on the peripheral vascular bed. Nature 209, 923-924 (1966)

2) Shanks, R.G.: The peripheral vascular effects of propranolol and related compounds. Brit. J. Pharmacol. 29, 204-217 (1967)

3) Himori, N., IzUmi, A. AND Ishimori, T.: Analysis of the vasodilator action of alprenolol. 
Europ. J. Pharmacol. 47, 341-350 (1978)

4) Giudicelli, J-F., Schmitt, H. ANd Boissier, J.R.: Studies on dl-4-(2-hydroxy-3-isopropylaminopropoxy)-indole (LB46), a new potent beta adrenergic blocking compound. J. Pharmacol. exp. Ther. 168, 116-126 (1969)

5) YabuUchi, Y. AND Kinoshita, D.: Cardiovascular studies of 5-(3-tert-butylamino-2hydroxy)propoxy-3,4-dihydrocarbostyril hydrochloride (OPC-1085), a new potent $\beta$-adrenergic blocking agent. Japan. J. Pharmacol. 24, 853-861 (1974)

6) Scriabine, A., Torchiana, M.L., Stavorski, J.M., Ludden, C.T., Minsker, D.H. and StONE, C.A.: Some cardiovascular effects of timolol, a new $\beta$-adrenergic blocking agent. Archs int. Pharmacodyn. Thér. 205, 76-93 (1973)

7) Himori, N. ANd Izumi, A.: Change in automaticity of excised, sino-atrial node by alprenolol and its dextro isomer and several drugs injected into the sinus node artery of the dog. Archs int. Pharmacodyn. Thér. 230, 245-256 (1977)

8) Fleckenstein, A., Kammermeier, H., Döring, H.J. and Freund, H.J.: Zum Wirkungsmechanismus neuartiger Koronardilatatoren mit gleichzeitig Sauerstoff-einsparenden Myokard-Effekten, Prenylamin und Iproveratril. Z. Kreislaufforsch. 56, 716-744 (1967)

9) ÅBlad, B., Brogärd, M., CARLSSON, E. AND EK, L.: $\beta$-Adrenergic receptor blocking properties of three allyl-substituted phenoxypropanolamines. Europ. J. Pharmacol. 13, 59-64 (1970)

10) Barrett, A.M.: Drug design, Edited by Ariëns, E.J., Vol. 3, p. 205-228, Academic Press, New York and London (1972)

11) Mylecharane, E.J. and Raper, C.: Nitrilophenoxypropanolamines: Influence of ring substitution on $\beta$-receptor blackade. Europ. J. Pharmacol. 29, 93-101 (1974)

\title{
ORAL SELF-ADMINISTRATION OF MORPHINE IN RATS
}

\author{
Saizo YANAURA, Jiro UESUGI, Tsutomu SUZUKI \\ and Teiko KAWAI* \\ Department of Pharmacology and ${ }^{*}$ Department of Psychology, \\ Hoshi College of Pharmacy, Shinagawa-ku, Tokyo 142, Japan
}

Accepted November 9, 1979

The operant behavior method has been utilized to ascertain whether certain drugs have the power to reinforce the animal's operant behavior and also whether the animal can self-administer the drug by means of automatic intravenous or intragastric injections (1-5). Using operant behavior the oral self-administration of morphine has been little studied though the preference for morphine has been reported (6-8). In our present work, the operant discrimination behavior was used with the drug-admixed food method $(9,10)$ to examine the oral self-administration of morphine.

A Skinner discrimination box $(25 \times 20 \times 30 \mathrm{~cm})$ was used; two sets of levers, food trays and small lights were attached to the inside of the box. Two food dispensers outside the box were connected to the food trays by tubes (developed by our department and Charles River Japan, Inc., Kanagawa). Ordinary pellet food, weighing approx. $45 \mathrm{mg}$, was from the CLEA Japan, Inc. and the same type of pellet food which was produced by mixing morphine hydrochloride $(1 \mathrm{mg} / \mathrm{g}$ food) into normal food was prepared in our department 